\section{Summary}

It has been claimed that a raised blood lead level is a common finding among mentally retarded children and that this is of aetiological significance. One hundred and twenty-three mentally handicapped children of uncertain aetiology, 24 with mongolism, and 73 controls have been examined for lead intoxication. The results indicate that the three groups do not differ significantly as regards blood lead levels and no definite evidence of either acute or chronic lead poisoning has been obtained.

This study does not suggest that these mentally backward children have been particularly at risk from lead poisoning, and emphasizes the limited value of an isolated estimation of the blood lead level. These conclusions do not depend on whether 36 or $50 \mu \mathrm{g}$. of lead per $100 \mathrm{ml}$. of blood is regarded as the upper limit of normal. However, if a value is found which is above the accepted level for the population in a particular area, this is an indication for further investigation, but not necessarily for treatment.

We wish to express our thanks to Mrs. J. H. Kellgren for all the time and effort she gave to collecting the data on the patients in this study.

\section{REPERENCES}

Byers, R. K. (1959). Pediatrics, 23, 585.

Chisolm, J. J., jun. (1965). Develop. Med. child Neurol., 7, 529.

King, E., and Thompson, A. R. (1961). Ann. occup. Hyg., 3, 247. Moncrieff, A. A., Koumides, O. P., Clayton, B. E., Patrick, A. D., Renwick, A. G. C., and Roberts, G. E. (1964). Arch. Dis. Childh., 39, 1.

Whitaker, J. A., Austin, W., and Nelson, J. D. (1962). Pediatrics, 29, 384.

\title{
Heparin Administration by Constant Infusion Pump
}

\author{
ANTHONY J. HANDLEY,* M.B., B.S.
}

Brit. med. F., 1967, 2, 482-484

This paper presents a method for the continuous intravenous infusion of heparin by means of a syringe-pump, and compares it with the technique of intravenous drip infusion (Harden, 1963).

\section{Methods}

The syringe-pump used was that described by Pegg et al. (1963). It consists of a small constant-speed mains electric motor which rotates a screw thread. This in its turn drives home the plunger of a standard glass syringe (see illustration ${ }^{1}$ ).

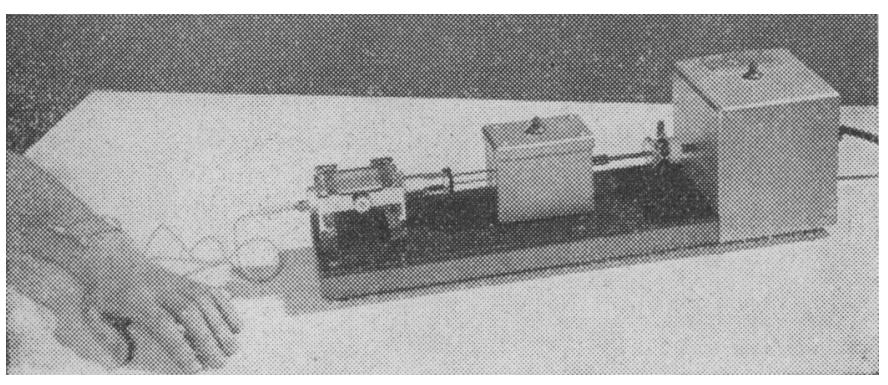

Syringe-pump connected to a patient.

The pump is regulated to give a steady infusion of $20 \mathrm{ml}$. in 12 hours. Two anaesthesia extension sets (Baxter model R33), each 12 in. $(30 \mathrm{~cm}$.) long, are used to connect the syringe to the patient. Both the syringe and the extension sets are filled with heparin solution of the required strength.

A suitable forearm vein is selected, and a Portex 12-in. (30cm.) nylon intravenous cannula size 16 with terminal Luer fitting inserted by means of an introducing needle as described by Macgregor (1960). The arm requires little or no splinting, and the length of extension tubing used allows the patient considerable movement.

The following assessment of this technique and the dripinfusion technique of Harden (1963) was made.

- House-physician, Westminster Hospital, London S.W.1. Present eddress: The London Hospital, Whitechapel, London E.1.

1 The pump described was made in the Physics Department, Westminster Hospital. Syringe-pumps of various designs are available commercially, and a list of known suppliers will be furnished on request to the author.

\section{Results}

Twenty-four patients suffering from thromboembolic disease were treated with heparin : 18 were given it by pump infusion and six by drip infusion. The degree of anticoagulation produced was measured by the whole-blood clotting-time, a modification of the Lee and White (1913) method being used. Venous blood was taken from the arm not used for the heparin infusion.

The mean clotting-time of the 24 patients before starting heparin was 4.8 minutes, with a range of 3.5 to 6.5 minutes. The mean clotting-time of 12 normal controls by the same method was 4.75 minutes, with a range of 3.5 to 5.5 minutes.

Pump Infusion. - Of the first 12 patients treated by pump infusion, 10 were given 20,000 units of heparin over each 12hour period that the syringe pump ran. One patient (Case 1) was given 24,000 units and one (Case 9) was given 7,000 units over each 12-hour period. The average length of treatment was 7.3 days, with a range of 1 to 14 days. During heparin therapy six random clotting-times were estimated for each patient, spread out so far as was possible over the whole period of treatment. The results are shown in Table $I$. Of the patients receiving 20,000 units of heparin in 12 hours, only two (Cases 10 and 11) had a mean clotting-time outside the range of 2.4 to 3.5 times their normal (pre-heparin) times. This probably represents optimum anticoagulation (Duff et al., 1951 ; Wood, 1956 ; Carey and Williams, 1960 ; Griffith and Boggs, 1964 ; Brigden, 1966). The mean clotting-time in Case 1 was 4.2 times normal, and in Case 9 it was 2.3 times normal.

Loading-dose.-The effect of an initial "loading-dose" of heparin was studied in six further patients; three were given 5,000 units of heparin intravenously at the time the syringepump was started, and three were given no such loading-dose. Clotting-times were measured before treatment, at half-hour and two hours after the pump was started, and on two further random occasions. The results are shown in Table II. An the patients eventually achieved satisfactory clotting-times. In the three receiving no loading-dose of heparin the clotting-times at half an hour were uniformly unsatisfactory (less than twice normal) and at two hours one (Case 18) was unsatisfactory and one (Case 17) barely satisfactory. In the three patients receiving the 5,000 units initial loading-dose, the half-hour and two-hour clotting-times were all very near the final clotting-times achieved. 
TABle I.-Results of Six Random Clotting-times on Patients Receiving Heparin by Pump Infusion. All Received 20,000 Units in 12 Hours Except Cases 1 and 9

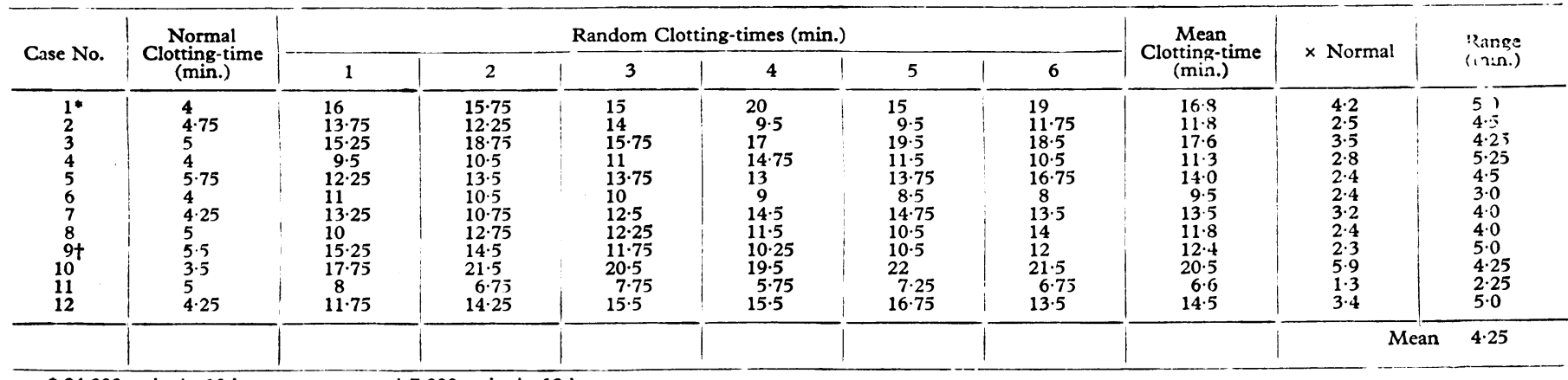

- 24,000 units in 12 hours.

$+7,000$ units in 12 hours.

Drip-infusion.-Six patients were treated with 20,000 units of heparin in $500 \mathrm{ml}$. of $5 \%$ dextrose solution, administered over 12 hours by drip infusion. Control clotting-times and six random clotting-times were measured. The results are shown in Table III. The nursing staff were instructed to watch the infusions very carefully and to regulate them to run at a constant speed over the full 12 hours. The mean clottingtimes were similar to those obtained from patients on pump

TABLB II.-Effect on the Half-hour and Two-hour Clotting-times of TABLB I1.-Effect on the Half-hour and Two-hour Clotir
5,000 Units of Heparin as a "Loading-dose"

\begin{tabular}{|c|c|c|c|c|c|c|}
\hline \multirow{2}{*}{$\begin{array}{l}\text { Case } \\
\text { No. }\end{array}$} & \multirow{2}{*}{$\begin{array}{c}\text { Normal } \\
\text { Clotting- } \\
\text { time } \\
\text { (min.) }\end{array}$} & \multicolumn{3}{|c|}{$\begin{array}{l}\text { Clotting-times } \\
\text { (min.) }\end{array}$} & \multicolumn{2}{|c|}{$\underset{(\mathrm{min} .)}{\text { Random }}$} \\
\hline & & $\frac{1}{2}$ hour & & 2 hours & 1 & 2 \\
\hline & \multicolumn{6}{|c|}{5,000 units loading-dose } \\
\hline \multirow[t]{2}{*}{$\begin{array}{l}13 \\
14 \\
15\end{array}$} & $\begin{array}{l}4 \cdot 25 \\
4 \cdot 75 \\
4 \cdot 75\end{array}$ & $\begin{array}{l}14 \cdot 75 \\
12 \\
21 \cdot 5\end{array}$ & 1 & $\begin{array}{l}13.5 \\
12.5 \\
17.5\end{array}$ & $\begin{array}{l}14 \cdot 5 \\
12 \cdot 25 \\
15\end{array}$ & $\begin{array}{l}14 \\
13 \\
17 \cdot 25\end{array}$ \\
\hline & \multicolumn{6}{|c|}{ No loading-dose } \\
\hline $\begin{array}{l}16 \\
17 \\
18\end{array}$ & $\begin{array}{l}5 \\
5 \\
4 \cdot 25\end{array}$ & $\begin{array}{l}6 \cdot 5 \\
6 \\
5\end{array}$ & 1 & $\begin{array}{l}11 \cdot 5 \\
10 \\
8.75\end{array}$ & $\begin{array}{l}14 \cdot 5 \\
16 \\
13 \cdot 75\end{array}$ & $\begin{array}{l}14 \cdot 5 \\
17 \\
12 \cdot 25\end{array}$ \\
\hline
\end{tabular}

Infusion (as might be expected since similar doses were used), but most ranges have been marred by one or two very long or short times. This is in keeping with the belief that drips, by and large, are very difficult to maintain at constant speed (Duff et al., 1951). The clotting-time ranges for patients on pump infusion were significantly smaller than the ranges for patients on drip infusion (Mann-Whitney $U$ test gives $P<0.001$ ). The mean range for the pump-infusion group was 4.25 minutes, and for the drip-infusion group it was 12.5 minutes.

Complications of Treatment.-There were no haemorrhagic complications of heparin therapy. Early in the series 18-gauge intravenous cannulae were used with the syringe-pump and three became blocked during use. Later 16-gauge cannulae were used and blockage was not encountered. Two instances of cannula blockage occurred in the patients on drip infusion, for which 16-gauge cannulae were used. Superficial thrombophlebitis occurred in 3 of the 18 patients on pump infusion, and in one of the six patients on drip infusion. The cannulae were reinserted into the opposite forearms. Early in the series a few episodes of faulty management of the syringe-pump by the nursing staff were encountered. Further instruction eliminated this. With a 12 -hour pump the syringe changes can all be carried out at a time convenient to the medical staff and need not be entrusted to nurses. Once the principles were understood, however, little difficulty was encountered.

\section{Discussion}

It would seem logical to attempt to control anticoagulation by heparin in the same way as it is controlled by the oral drugs (Brit. med. F., 1966).

Administration of heparin by continuous intravenous drip infusion has been advocated to avoid the great variations in clotting-time which occur if heparin is given by intermittent intravenous injection (Bauer et al., 1950 ; Harden, 1963). The syringe-pump described has been found by us to maintain : more constant infusion rate (as reflected by the significantiy more consistent clotting-times) and to require less supervision than the continuous drip infusion, even when the latter was used under ideal conditions-namely, in a well-staffed teaching hospital with a high nurse/patient ratio. In many peripheral hospitals the shortage of good nursing staff and facilities is likely to magnify enormously the problem of keeping a drip infusion running at a constant rate.

The volume of fluid infused per day by the syringe-pump is under $50 \mathrm{ml}$., compared with $1,000 \mathrm{ml}$. by the drip infusion. If the drip is run at a slower speed, further inaccuracies in rate and a tendency for the cannula to block may occur. Though most patients will tolerate a litre of intravenous fluid a day, in cases of cardiac and renal failure this may be dangerous (Duff et al., 1951 ; Goodman and Gilman, 1965).

\section{Control in Use}

The following regimen is suggested for the use and control of heparin therapy by the method of pump infusion:

1. When the decision to anticoagulate has been taken the patient's normal clotting-time is estimated.

2. Heparin (5,000 units) is injected intravenously to obtain rapid anticoagulation.

3. The syringe-pump is set up as described above and, initially, heparin is administered at the rate of 20,000 units per 12 hours.

Table III.-Results of Six Random Clotting-times on Patients Receiving Heparin by Drip Infusion. All Received 20,000 Units in 12 Hours

\begin{tabular}{|c|c|c|c|c|c|c|c|c|c|c|}
\hline \multirow{2}{*}{ Case No. } & \multirow{2}{*}{$\begin{array}{c}\text { Normal } \\
\text { Clotting-time } \\
\text { (min.) }\end{array}$} & \multicolumn{6}{|c|}{ Random Clotting-times (min.) } & \multirow{2}{*}{$\begin{array}{c}\text { Mean } \\
\begin{array}{c}\text { Clotting-time } \\
\text { (min.) }\end{array} \\
\end{array}$} & \multirow{2}{*}{$\times$ Normal } & \multirow{2}{*}{$\begin{array}{l}\text { Range } \\
\text { (min.) }\end{array}$} \\
\hline & & 1 & 2 & 3 & 4 & 5 & 6 & & & \\
\hline \multirow[t]{2}{*}{$\begin{array}{l}19 \\
20 \\
21 \\
22 \\
23 \\
24\end{array}$} & $\begin{array}{l}4 \cdot 25 \\
6 \cdot 5 \\
5 \cdot 5 \\
5 \\
6 \\
6\end{array}$ & $\begin{array}{c}20 \cdot 25 \\
17 \cdot 5 \\
16 \cdot 75 \\
6 \\
18 \cdot 25 \\
20 \cdot 75\end{array}$ & $\begin{array}{c}24 \\
6.5 \\
16 \cdot 5 \\
6 \cdot 5 \\
29 \\
23 \cdot 25\end{array}$ & $\begin{array}{l}14 \cdot 75 \\
16 \\
26 \\
9 \cdot 75 \\
15 \cdot 5 \\
17 \cdot 75\end{array}$ & $\begin{array}{c}10 \cdot 25 \\
23 \cdot 5 \\
21.5 \\
6.75 \\
13 \cdot 5 \\
29 \cdot 25\end{array}$ & $\begin{array}{r}7 \cdot 75 \\
23 \cdot 75 \\
21 \cdot 75 \\
8 \cdot 75 \\
21 \cdot 25 \\
25 \cdot 5\end{array}$ & $\begin{array}{l}7 \cdot 5 \\
22 \cdot 25 \\
22 \\
11 \\
16 \cdot 25 \\
25\end{array}$ & $\begin{array}{r}14.1 \\
18.3 \\
20.8 \\
8.1 \\
19.0 \\
23.9\end{array}$ & $\begin{array}{l}3 \cdot 3 \\
2.8 \\
2.8 \\
1.6 \\
3.2 \\
4 . j\end{array}$ & $\begin{array}{c}16.5 \\
17.25 \\
9.5 \\
5.0 \\
15.5 \\
11.5\end{array}$ \\
\hline & & & & & & & & & Mean & $12 \cdot 5$ \\
\hline
\end{tabular}


4. After three to four hours a further estimation of the patient's clotting-time is made. If this is not within an acceptable range, a suitable adjustment in dosage is made.

5. Further estimations of the patient's clotting-time should probably be made daily, to confirm that the anticoagular:: effect is being maintained.

\section{Summary}

A method of continuous intravenous infusion of heparin with a syringe-pump is described. By this method very constant and easily controllable prolongation of the patient's whole-blood clotting-times were obtained.

Reliability, easy supervision, comfort for the patient, and a small volume of intravenous fluid are advantages of this technique. A suggested regimen for the control of heparin therapy is given.

I am indebted to Dr. P. A. Emerson for his help and encouragement with this paper; to Dr. C. J. Gavey for permission to study patients under his care; and to Dr. J. Russell Rees for much advice. My thanks are also due to Mr. John Fleetcroft, a medical student, who did many of the clotting-time estimations. The Department of Medical Photography, Westminster Medical School, kindly provided the photograph.

\section{REFERENCES}

Bauer, G., Boström, H., Jorpes, E., and Kallner, S. (1950). Acta med. scand., 136, 188.

Brigden, W. (1966). In Price's Textbook of the Practice of Medicine, 10 th ed., edited by R. B. Scott, p. 697. London.

Brit. med. 7., 1966, 1, 693.

Carey, L C., and Williams, R. D. (1960). Ann. Surg., 152, 919.

Duff, I. F., Linman, J. W., and Birch, R. (1951). Surg. Gymec. Obster., 93, 343.

Goodman, L. S., and Gilman, A. (1965). The Pharmacological Basis of Therapeutics, 3rd ed., p. 1448. New York.

Griffith, G. C., and Boggs, R. P. (1964). Amer. F. Cardiol., 14, 39.

Harden, R. McG. (1963). Brit. med. Y., 2, 1106.

Lee, R. I., and White, P. D. (1913). Amer. Ұ. med. Sci., 145, 495.

Macgregor, J. D. (1960). Lancet, $1,528$.

Pegg, D. E., Trotman, R. E., and Pierce, N. H. (1963). Brit. med. J., 1, 1207.

Wood, P. (1956). Diseases of the Heart and Circulation, 2nd ed., p. 817. London.

\section{Medical Memoranda}

\section{Use of the Quinton/ Scribner Arteriovenous Shunt in Management of Aplastic Anaemias}

Brit. med. F., 1967, 2, 484-485

The original concept of a Teflon arteriovenous shunt for the treatment of acute renal failure by repeated haemodialysis was presented, with a description of a successful prosthesis, by Quinton, Dillard, and Scribner (1960). The further development of this to the Teflon/Silastic shunt described by the same authors (Quinton, Dillard, Cole, and Scribner, 1962) provided the fundamental requirement for chronic intermittent haemodialysis. The use of this shunt has since become almost universal in artificial kidney units, and a recent article has described the technique of its insertion to those with more general interests (Clark and Parsons, 1966).

It was for these reasons, and against a background of considerable experience in shunt management, that further uses for the arteriovenous fistula were sought; one of the first suggested was in the treatment of the aplastic anaemias.

In the management of these difficult cases one of the major problems is that of repeated blood transfusions. The veins become thrombosed and obliterated, and the development of deeper collateral vessels under a thickened siderofibrotic skin presents a serious technical problem to venepuncture. So the

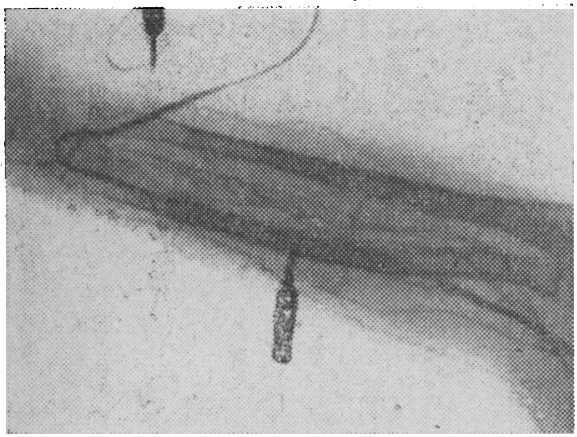

FIG. 1

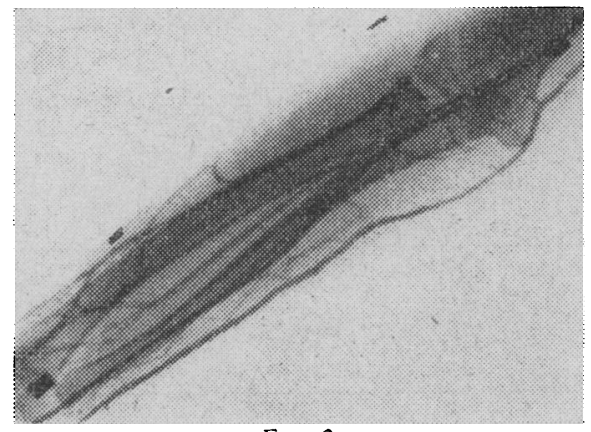

The patient was first admitted to hospital at the age of 11 weeks with anaemia. A sternal marrow showed decreased erythropoietic activity and from this time he required regular blood transfusions to maintain an adequate haemoglobin. By the age of 21 he had been given 400 units of blood or cells and had been transfused approximately 150 times. He was $4 \mathrm{ft} .8 \mathrm{in}$. $(1.5 \mathrm{~m}$.) tall and showed signs of infantilism; he had hepatospleno- 